\title{
Project Manager and Stress in Coping with Demanding Situations in Automotive Industry
}

\author{
Róbert Modranský a ${ }^{a}$ Kateřina Bočková ${ }^{\text {b*}}$, Michal Hanák ${ }^{\mathrm{b}}$ \\ ${ }^{a}$ Faculty of Management, Prešov University in Prešov, Konštantínova 16, Prešov, Slovakia \\ ${ }^{b}$ DTI University, Sládkovičova 533/20, Dubnica nad Váhom, Slovakia
}

\begin{abstract}
Coping with demanding situations is a part of managerial work at different levels and in different contexts. In the presented paper, based on the theoretical and methodological analysis of knowledge in the field of coping and special coping with demanding situations in project manager work, we present the results and knowledge related to the possibility of researching and identifying procedures for coping with demanding situations in project management. Attention is focused on the identification of ways of coping with demanding situations in project manager work through the BSMW Questionnaire - Behaviour Strategies in Managerial Work as a tool for identifying these procedures. We present findings related to the analysis of the assessment of strategies for managing demanding situations in project manager work in Slovak automotive industry in the context of selected personality, socio-demographic characteristics of managers and situational conditions. The acquired results verified the meaningfulness of the empirical-inductive principle of detecting the ways of coping with the examined demanding situations and determining the taxonomy of these principles with the specification of five factors - emotional factor of coping, cognitive factor of coping I, cognitive factor of coping II, behavioural factor of coping I and behavioural factor of coping II. From the methodological viewpoint our results contribute to the discussion about the interactional approach in research in social sciences and about the question of dispositional or situational conception of methods of researching in this area of knowledge.
\end{abstract}

\section{Keywords:}

Management;

Manager;

Coping;

Demanding Situations.

\section{Article History: \\ Received: 11 July 2020 \\ Accepted: $\quad 30 \quad$ September 2020 \\ Published: 01 October 2020}

\section{1- Introduction}

Demanding situations are a part of our real being. They have been, they are and they will appear in our lives forever. The field of management, i.e. project management, is one of the typical environments in which the occurrence of the difficult situations is not uncommon. Meetings of the project manager with the demanding situations, the ways of their solution and the residual of these processes can significantly affect the quality of his life, existence, and mental and physical health and ultimately the effectiveness of his managerial activities and the success of the project and project team, so they finally affect other people as well. At present, therefore, experts in the field of human sciences are increasingly focusing on issues of the perception, experience and effective resolution of the demanding situations in management, but their attention is not escaped by the conditions that caused these situations and their solution.

Project managers get into the demanding situations on a daily basis and when solving them, they often have to mobilize all their forces once with bigger, sometimes with less success in managing them, and there are also cases when they fail in these situations.

The level of difficulty, complexity and stress of a demanding situation must be understood in the context of the situational conditions of the project in a particular organization and the characteristics of a particular project manager.

\section{*CONTACT: Bockova@dti.sk \\ DOI: http://dx.doi.org/10.28991/esj-2020-01241}

(C) 2020 by the authors. Licensee ESJ, Italy. This is an open access article under the terms and conditions of the Creative Commons Attribution (CC-BY) license (https://creativecommons.org/licenses/by/4.0/). 
The presented findings from the issue of coping with demanding situations with an emphasis on the coping with these situations in project manager work confirm the fact that this issue has long been paid attention, which corresponds to the amount of knowledge we have in this area, for example cited and described in Frankovský et al. (2012), Gabrhelová (2020), Unaldi (2020) and Petru and Jarošová (2019) studies [1-4]. Despite a certain conceptual ambiguity, the inconsistency of the results of individual researches, various methodological approaches, the area of the research of coping with demanding situations in the different life contexts forms a relatively consistent area of knowledge.

In the presented paper, we therefore focus on the solving issues related to the ways of coping with demanding situations in the work of a project manager, on the possibilities of identifying and predicting the behaviour of project managers in these situations and on the relationship between coping and factors that occur in the context of demanding situations.

\section{2- Problem Formulation and Methodology}

The essential of the presented paper is based on the theoretical analysis and theoretical elaboration of the issue based mainly on Lajčin et al. (2012), Frankovský et al. (2012) and Lajčin and Frankovský (2012) results [5-7] to enrich the knowledge and to contribute in the theoretical and practical level to solve the demanding situations in the specific life context of project manager work.

The project of the research part of the presented paper is focused on the verification of the new original methodology for identifying the ways of managing the demanding situations in the project manager work, which was created by Lajčin in DTI University and validated in Lajčin et al. (2012), Lajčin and Frankovský (2011) and Lajčin and Korn (2016) researches [5, 8, 9]. Subsequently, to characterize the relationship between the mentioned ways of coping and selected factors representing the situational and personal context of coping with the demanding situations in the work of a project manager.

Based on the presented paper essential, we formulated this research problem RP and hypothesis H1, which will be solved within the research project:

Research Problem RP: Are there significant connections between selected personality characteristics of project managers and how these managers assess the ways of coping with the demanding situations in their work?

Hypothesis H1: We assume that there are significant connections between the selected personality characteristics of project managers and how these managers assess the ways of coping with the demanding situations in their managerial work.

In the presented research we analysed data obtained from 174 respondents, project managers working in Slovak automotive companies. Managers included into the research had technical education - 92 respondents, science education - 13 respondents and social education 69 respondents. The research sample included 46 single project managers, 106 married, 19 divorced and 3 widowed project managers. Project managers who participated in the research had an average age of 36.5 years (ranging from 21 years to 64 years) with a standard deviation of 8,391 years.

In practice, they generally worked for an average of 15.3 years (standard deviation 8.420) and for the position of project manager they worked for an average of 6.9 years (standard deviation 6.311). From this data, it is clear that in the context of the length of practice in a managerial position, the research sample included both beginning project managers and managers with many years of experience (maximum 38 years). The data and information needed to verify the hypothesis were obtained from the respondents using three questionnaires. Using these methodologies, data were obtained on:

- The strategies for managing of the demanding situations in the project manager work,

- The selected personality characters of project managers,

- The basic socio-demographic characteristics of respondents.

Specifically, the following research methodologies were used in the presented research, which determined the assessment of the preference of individual strategies for coping with the demanding situations:

- BSMW Questionnaire - Behaviour Strategies in Managerial Work,

- CSI methodology - Coping Strategy Indicator published in Amirkhan (1990) [10],

- IAS - Interpersonal Adjective Scales issued by Wiggings (1995) [11].

Data obtained from respondents, project managers, were processed and analysed using following mathematical and statistical methods:

- Descriptive statistics (frequency of occurrence, arithmetic mean, standard deviation),

- Methods of inductive statistics (Pearson correlation coefficient, Student's t - test, One Way ANOVA, Tukey' s post hoc comparison test), 
- Advanced statistical methods (factor analysis - Principal Component Analysis with Varimax rotation, Cronbach's alpha).

All calculations were performed in the statistical software SPSS 18.

\section{3- Overview of the Current State of the Issue}

The growing interest of the professional and lay public in the issue of coping with the demanding situations can be dated to the early 80s, as cited in Folkman and Lazarus (1980), Lazarus (1998), Lazarus and Folkman (1984), Folkman (1986), Lazarus and Folkman (1987), Carver et al. (1989), Nurmi et al. (1996) and Folkmand and Moskowtz (2004) studies [10, 12-19]. Lajčin and Korn (2016) and Gabrhelová and Korn (2016) in their work [9, 20] state that this interest is a reflection of the general rapid dynamics of people's lives (the need for mechanisms to democratically address societal problems, the growing number of demanding situations in our lives, the growing interest in how to cope effectively with these situations, what impact have on the psyche, health and well-being of a person, addressing quality of life, etc.), as well as of the specific requirements of social practice (new approach and development of managerial activities, effective functioning of the organization, the need to take unpopular measures, time stress in decision-making, conflicts in the workplace, team building, etc.).

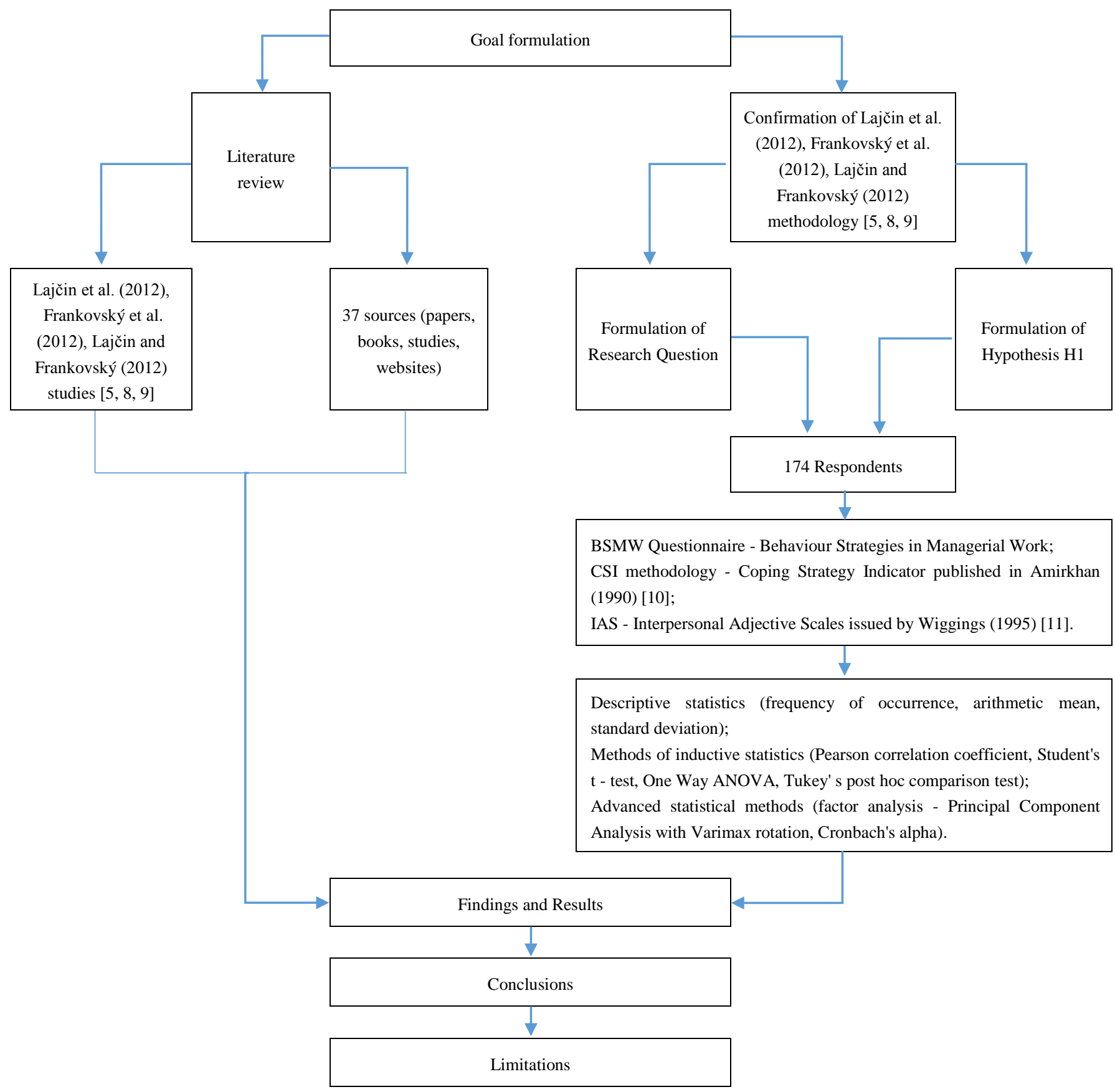

Figure 1. Methodology Scheme. 
If a person gets into a difficult situation, the focus is on solving the situation, considering the possible procedures, obtaining the necessary information, seeking help, finding the escape options, etc., Oberuč et al. (2014) argues in their work [21].

Answering a question and explaining what is a demanding situation, how to identify it, which situations people rate as stressful, problematic, conflicting, complex, uncomfortable, recedes into the background, is not a priority, Frankovský et al. (2012) [1] claimed, and paradoxically devoted to the characteristics of the situation less attention than questions of how one handles these situations, what forms of behaviour one chooses, how one solves them. From the point of view of the needs of the organization, but also of a specific manager, it is logical. For representatives of all these positions, the decisive factor is how the manager handles the situation, how he behaves in it, how he manages it, and how effective his activity is [7].

This fact then directs the attention of most researchers, for example Stewart and Philip (2007) or Aitken and Crawford (2007) studies [22, 23] in the direction of the analysis of behaviour and its predictors related to the characteristics of the project manager or the characteristics of the demanding situation.

At the same time, the question of what is a demanding situation, resp. what kind of situation a person perceives as demanding, is crucial, both in the context of its identification and its solution as well. The answer to this question is essential both in terms of preparing managers to deal with different types of demanding situations and of developing specific procedures in the organization to deal with certain demanding situations [6].

Albrecht (2010) [24] states that the perception of the degree of the difficulty of the situation varies from person to person. It is obvious that, for example, a change in production, assortment of sales is for certain project managers just a common routine work, which they do not perceive as stress, burden, and unpleasant situation. On the contrary, other managers may perceive the same situation as demanding, stressful, unpleasant. Coping with this situation requires from them maximum commitment, control and personal coping with this situation.

Lusch and Jaworski (1991) [25] adds that the very complexity of the situation can be considered on the one hand as a threat, a fear of failure, but on the other hand, it can be perceived as a challenge, an incentive to embark on something new, to prove its qualities, to assert itself.

It is clear from these examples that the effect of the level of difficulty itself must be interpreted both in the context of the situational characteristics in which coping takes place and in the context of the personality characteristics of a particular manager who is an actor in this coping.

Despite the above, individual research approaches to the classification of these situations create a relatively separate, specific line, its own dimension of research across the interrelationships of causes and consequences in the system of the situation and its solution. The individual approaches following this line usually result in the design of an empirical taxonomy and a classification of the demanding situations.

The current work environment, whether internal or external, and not only of project managers in the automotive industry, is significantly and largely negatively affected by current events in connection with the global pandemic of COVID 19. This global situation causes a number of stressful situations not only at work, but in private life as well. It goes without saying that many theorists, but also practitioners, psychologists, doctors and HR professionals, are dealing with this situation. Current trends in the field of coping strategies for project managers are examined in more detail and described in Zhang et al. (2020), Karlsen and Berg (2020), Burrows (2020), WHO (2020) and Unterhitzenberger et al. (2020) studies [33-37] and we fully identify with the conclusions published here.

\section{4- Results and Discussion}

Exploring the relationship between personality characteristics as dispositional characteristics that predict people's behaviour in transit and coping with situations is one of the typical and can be said classical areas of coping research (Folkman and Moskowitz (2004) [19] examined 7 personality characteristics, Callan and Dickson (1993) [26] focused on control location, Hu and Cheng (2010) [27] on burnout syndrome, etc.).

In the presented research project, following the researched social context of the occurrence of the demanding situations in managerial work, we focused on the analysis of the relationship between behaviours identified by 5 factors of the BSMW methodology and personality characteristics specified by IAS according to Wiggins (1995) concept [11].

Five factors, which describe the tendency of managers to manage the demanding situations in the management of the organization in a certain way, were within the creation of Lajčin's BSMW methodology validated in Frankovský et al. (2012) and Lajčin and Frankovský (2011) research results [7, 8] extracted by factor analysis, the Principal Conpoment method with Varimax rotation was used. According to Frankovský et al. (2012) research results [1], these are the following factors: 
- Emotional coping factor. This factor is related to the emotional response to the situation. Unlike the following factors, this factor was extracted regardless of the context of the situation.

- Cognitive coping factor I. The content of this factor is not an immediate behavioural reaction, but thinking, looking for more information about a situation with a strong social context.

- Cognitive factor of coping II. Again, the content of this factor is not an immediate behavioural reaction, but thinking, finding other information about the situation, which is related to general problems in managerial work.

- Behavioural management factor I. This factor is related to the immediate behavioural response, in the context of solving situations that represent general problems in managerial work.

- Behavioural management factor II. This factor is related to the immediate behavioural response, in terms of dealing with situations with a strong social context.

This proposed five-factor structure of ways to cope with demanding situations has been sufficiently validated in Frankovský et al. (2012) and Lajčin and Frankovský (2011) research studies [1,8]. Therefore, it is possible to apply this methodology to the analysis of connections and differences between selected personality characteristics of project managers, situational conditions, socio-demographic characteristics of project managers and extracted factors of the multidimensional methodology to identify ways of coping with the demanding situations in project manager work.

The results we found, confirmed the expected relationship between behaviours in demanding situations of managerial work and characteristics of the interpersonal behaviour of project managers (Tables 1 and 2).

Table 1. Correlations between behaviours in demanding situations of project manager work and characteristics of the interpersonal behaviour of managers.

\begin{tabular}{ccccc}
\hline & PA & BC & DE & FG \\
\hline Emotional coping factor & -0.115 & -0.151 & -0.119 & $0.158^{*}$ \\
Cognitive coping factor I. & -0.014 & $-0.174^{*}$ & $-0.208^{* *}$ & -0.019 \\
Cognitive coping factor II. & 0.012 & 0.074 & -0.034 & -0.041 \\
Behavioural management factor I. & -0.061 & -0.101 & -0.058 & -0.108 \\
Behavioural management factor II. & $0.172^{*}$ & -0.111 & -0.088 & $-0.186^{*}$ \\
\hline
\end{tabular}

Table 2. Correlations between behaviours in demanding situations of project manager work and characteristics of the interpersonal behaviour of managers-continuation.

\begin{tabular}{ccccc}
\hline & HI & JK & LM & NO \\
\hline Emotional coping factor & $0.208^{* *}$ & 0.102 & 0.129 & 0.092 \\
Cognitive coping factor I. & 0.092 & 0.084 & 0.119 & 0.018 \\
Cognitive coping factor II. & 0.001 & 0.005 & 0.078 & -0.029 \\
Behavioural management factor I. & 0.064 & 0.026 & 0.001 & -0.017 \\
Behavioural management factor II. & $-0.202^{* *}$ & 0.091 & 0.108 & $0.214^{* *}$ \\
\hline
\end{tabular}

Legend: PA - self-assured, dominant, BC - arrogant, calculating, DE - cold, cold-blooded, FG - exalted, introverted, HI uncertain, submissive, JK - not important, supple, subtle, LM - warm, conciliatory, $N O$ - sociable, extraverted

The way of coping characterized by an emotional reaction correlated with the personality characteristics - uplifted, introverted, uncertain, submissive. This means that managers are more introverted and unsure, submissive, more prone to this way of coping.

The way of coping with the demanding situations in project manager work characterized as cognition I negatively correlated with the personality characteristics arrogant, calculating, cold, cold-blooded. The above cited correlation testifies to the fact that this way of dealing with situations with a strong social context is not preferred by arrogant, calculated, cold, cold-blooded managers.

We also found statistically significant correlations between the assessment of the coping style specified as behaviour II and personality characteristics of project managers as self-confident, dominant, sociable, extraverted positive correlation and negative correlation between this coping factor and personality characteristics of project managers as uplifted, introverted, uncertain, and submissive. This means that this way of dealing with situations with a strong social context is again preferred by self-confident, dominant, sociable, extroverted project managers and not preferred by introverted, insecure, submissive project managers.

The above analyses of the relationship between the personality characteristics of project managers and ways of 
coping with demanding situations in project manager work confirmed the expected facts, even at the hypothesis level, the significant relationship between selected features of interpersonal behaviour with some ways of coping with difficult situations.

Introverted, insecure, submissive project managers have stronger tendency to emotional reactions (it is annoying, such a situation is an unpleasant experience for me) when dealing with researched situations. On the contrary, selfconfident, dominant, sociable, extraverted project managers significantly less prefer emotional ways of dealing with demanding situations and prefer direct, immediate solutions to the situation. It should be noted that all these significant correlations have been confirmed in situations with a strong social context. This also corresponds to the IAS methodology used, which is focused on identifying features of interpersonal behaviour, i.e. personality characteristics with a strong social context.

Similar results in the analysis of the relationship between the features of interpersonal behaviour and strategies for coping with demanding situations, especially in terms of immediate resolution of the situation, were presented on the basis of research of the general population in Aitken and Crawford (2007), Baumgarten and Frankovský (2000) and Brougham (2009) studies [23, 28, 29]. Our results and findings suggest that hypothesis H1 has been confirmed.

The attention paid to the questions of how people behave, how they solve, how they manage demanding, stressful, crisis situations, which is documented by a diverse mosaic of research approaches and orientations of individual authors, shows that this issue is not on the periphery of scientific research, but also on peripheries of interest to practitioners.

The presented results, which result from our analysis, allowed to generalize this knowledge in the context of its theoretical benefits and development of knowledge in the field of science, as well as in the context of its practical benefits and usability for practice with emphasis on the application of knowledge in project manager work. Our findings clearly confirm the correctness of the multidimensional theoretical understanding of coping even in the context of the demanding situations in project manager work. The extracted and verified factor structure of ways of coping with these situations represents a new perspective on coping procedures in the face of demanding situations in project manager work, but also with difficult situations in life in general.

The characterized ways of coping basically represent a typical three-component structure of factors (cognition, emotions, behaviour), which can be found in other theoretical concepts (attitudes). In the context of research focused on the issue of coping, this is a new perspective on defining the structure of ways to cope with the demanding situations. Compared to the typical approaches, which are ultimately focused on characterizing problem-oriented coping or emotion-oriented coping, we can find some common characteristics. Behavioural factors in our conception are probably close to problem-oriented coping, while the emotional factor is close to emotionally oriented coping.

However, the concept that we specified in our work also emphasizes the cognitive component of coping, which certainly plays an important role in terms of solving the demanding situations in managerial work. Křivohlavý (1994) [30] classifies these management methods into a highly generalized solution to the demanding situations, which the author defined as active approaches. However, the distinction of behavioural and cognitive coping into two separate factors from the point of view of the context of the situation is not mentioned in the literature so far. This is evidenced by the fact that managers do not prefer behavioural and cognitive ways of coping with demanding situations universally, transversely, but the preference for these ways must be understood in the context of the situation. This not only confirms the findings of Armstrong (2008) and Mellahi and Wilkinson (2010) studies [31, 32], which, like other authors, pointed out the importance of accepting situational specifics when considering the behaviour of managers in different situations, but it is also an important finding in favour of validating the interaction concept of research, diagnosis and predictions of managers' behaviour in specific managerial situations.

Confirmation of the interrelationship of the personality, transitituation characteristics and conditions of a particular situation is important on the basis of the presented findings both at the theoretical level of generalization, in some cases in conflicting research results, as well as at the methodological level of development and application of measuring tools. At the same time, our results point to the need for a taxonomic approach to demanding situations. The presented distinction of these situations into two types (with social context and general) represents a high degree of abstraction from the specifics of really existing demanding situations. The question of the extent of this abstraction and thus also the level of generalization of the definition of the structure of demanding situations can be discussed and this issue will need to be given much more attention when examining the management of demanding situations in project manager work. The differentiated assessment of the preference of the individual ways of coping with demanding situations in managerial work testifies to the need to constantly consider the specifics of the particular life context of identifying and examining these processes. It is possible to assume that in the context of coping with demanding situations in managerial work we can specify general, highly generalized tendencies in managers' behaviour, which will characterize their behaviour in other areas of life, as well as specific manifestations conditioned by a specific situation that the manager has to manage (e.g. the relationships of the actors of the situation in conditions 
of superiority or subordination) and which are defined by the specificity of the occurrence of these situations in the management.

Findings and knowledge that can be generalized on the basis of our research have not only the above-mentioned theoretical and methodological benefits, but also a practical contribution to increasing the effectiveness of coping with demanding situations in project manager work. As already mentioned, we assumed that the issues examining of coping with these situations can affect this effectiveness in the context of selecting suitable candidates for managerial positions, their preparation and training in these positions, as well as designing ways to cope with demanding situations in the organizational management.

From this point of view, our results point to the need to take into account not only the generally accepted managerial competencies when selecting people for managerial positions, but also to take into account the specific requirements of a particular managerial position and the situation in which this manager will work. Effective selection of candidates for managerial positions is conditioned by the correct combination of the required general (education, practice, psychological profile, etc.) and specific competencies.

A very similar approach must be followed in the preparation of the management courses, training and education of managers in general. Generally conceived training activities for managers are not as effective as training, which is tailored to specific managers in specific managerial positions in specific managerial situations. This approach to the design of the managers' courses is also much more positively perceived by managers and also has a positive effect on the motivation of participants in education. However, it presupposes knowledge of the specifics of these managerial positions and situations that managers may encounter and that they must be able to manage, as well as the specification of ways of behaving in these situations. From the point of view of preparing systems for managing the demanding, often unexpected situations in the management of the organization, it is also necessary to pay attention to both common problems and demanding situations that we may encounter in each organization and for which it is possible to prepare generally valid procedures for their management, as well as challenging situations that are typical and specific only to a certain type of organization, respectively to a certain component of that organization.

Obviously, if an organization has defined and developed the procedures for coping with demanding situations, managers can handle these situations much more effectively if they occur in their work. According to our findings, the researched ways of coping with difficult situations in managerial work are related to the personality characteristics of managers. Introverted, insecure, submissive managers have a stronger tendency to emotional reactions when dealing with researched situations. On the contrary, self-confident, dominant, sociable, extraverted managers significantly less prefer emotional ways of dealing with difficult situations and prefer direct, immediate solutions to the situation. It should be noted that all of these have manifested themselves primarily in situations with a strong social context.

The presented results also point to the fact that the assessment of the preference of individual ways of coping with demanding situations in managerial work is not related to the areas of social practice of managers and is also not related to the level of position of managers. In this context, general managerial competencies play a decisive role, which are manifested as zhe dispositional characteristics of managers and, from the point of view of the area of social practice and the level of managerial position, they have a transitory effect. On the contrary, we found differences in the responses of managers in assessing the emotional factor and cognitive factor I. In both cases, the managers preferred the emotional response and cognitive processing, especially in situations with a social context.

The presented findings and conclusions represent only one of the possible angles of view of managerial work, its effectiveness, resp. opportunities to increase this efficiency. However, they testify to the fact that from the point of view of coping with demanding situations in managerial work it is possible to obtain significant results and knowledge enriching the theoretical and methodological level of knowledge in the management and managerial work and also significant findings usable in selecting people for managerial positions, their preparation and improvement, as well as in taking measures in the management system of the entire organization.

\section{5- Conclusion}

In the presented paper, we focused on one such specific moment in managerial work - coping with demanding situations, which, however, has its implications in the whole spectrum of managerial activities. We verified the validity of the new original methodology for identifying ways of coping with demanding situations in project manager work, which was created by Lajčin in 2011 at DTI University in the context of significant relationships between selected personality characteristics of managers and how managers assess ways of coping with demanding situations in their work. The results of our research confirmed the existence of five factors, which can be used to specify the structure of ways to cope with demanding situations in project manager work. At the same time, the extraction of two factors with cognitive content and two factors with behavioural content testifies to the need to take into account, when considering the ways to cope these situations and the possibility of predicting behaviour in them, the specific conditions of difficult situations, respectively the type of difficult situation. The presented findings point to the 
possibility of characterizing at least two types of situations - with a strong social context and with content that is not significantly social and is related to general problems of organizational management. The significance of the extracted factors was also confirmed by Cronbach's alpha coefficients and a validation study with the Coping Strategy Indicator (CSI) methodology described in Amirkhan (1990) [10].

The results of the research show that project managers would prefer a direct behavioural response - behavioural factor I especially in situations that do not have a strong social context and can rather be characterized as general problems in the organization (lack of finances, information leakage). From the point of view of assessment by individual managers, the least preferred strategy would be to describe the procedure as thinking, searching for further information in situations with a strong social context.

\section{6- Funding}

This work was supported by the IGA VŠDTI č. 004/2019 Project Team Members' Colors Preference in the Didactic Context of the Education at the Universities in Selected EU Countries provided by the DTI University, Dubnica nad Váhom, Slovakia.

\section{7- Conflict of Interest}

The author declares that there is no conflict of interests regarding the publication of this manuscript. In addition, the ethical issues, including plagiarism, informed consent, misconduct, data fabrication and/or falsification, double publication and/or submission, and redundancies have been completely observed by the authors.

\section{8- References}

[1] Frankovský, Miroslav, Lajčin, Daniel and Jiří Kern „Zvládanie náročných situácií v manažérskej práci.” Praha: RADIX. (2012).

[2] Gabrhelová, Gabriela, Stress- Analyse im Lehrerberuf.“ Karlsruhe: Ste-Con (2020).

[3] Unaldi Baydin, Nihal, Hanife Tiryaki Sen, Sevdan Kartoglu Gurler, Birsen Dalli, and Arzu Kader Harmanci Seren. "A Study on the Relationship Between Nurses' Compulsory Citizenship Behaviours and Job Stress.” Journal of Nursing Management 28, no. 4 (April 20, 2020): 851-859. doi:10.1111/jonm.13009.

[4] Petru, Jaroslav, and Eva Jarosova. "Exploring Impact of Coping Approaches on Intrinsic Perceived Overall Wellness: A Study of Executives and Senior Managers in Czech Republic." Central European Business Review 8, no. 3 (October 1, 2019): 54-68. doi:10.18267/j.cebr.215.

[5] Lajcin, Daniel, Miroslav Frankovsky, and Robert Stefko. "Possibilities of predicting the behavior of managers when coping with demanding situations in managerial work." Ekonomicky casopis 60, no. 8 (2012): 835-853.

[6] Frankovský, Miroslav, Lajčin, Daniel and Zuzana Birknerová "Coping with Demanding Managerial Work Situations in the Context of Personality Characteristics of Managers”. Tudományos mozaik, 8 no. 4 (2019): 231-238.

[7] Frankovský, Miroslav, Lajčin, Daniel and Gabriela Sláviková „Social intelligence as a predictor of managers' behaviour in demanding situations of managerial work.” Management (2012). 476-486.

[8] Lajčin, Daniel and Miroslav Frankovský „Zist’ovanie spôsobov zvládanie náročných situácií v manažmente podniku.” Journal of Management and Business: Research and Practice, 3 no. 5 (2011): 93-104.

[9] Lajčin, Daniel and Ferdinand Korn "Neutral Charge of Social Intelligence Manager for Morality in the Context of an Interdisciplanary View of Managers Social Intelligence." Management 2016: International Business and Management, Domestic Particularities and Emerging Markets in the Light of Research. Prešov University in Prešov (2016) 584-590.

[10] Amirkhan, James H. "A Factor Analytically Derived Measure of Coping: The Coping Strategy Indicator." Journal of Personality and Social Psychology 59, no. 5 (1990): 1066-1074. doi:10.1037/0022-3514.59.5.1066.

[11] Wiggins, Jerry S. "Interpersonal Adjective Scales.” Psychological Assessment Resources (1995).

[12] Folkman, Susan, and Richard S. Lazarus. “An Analysis of Coping in a Middle-Aged Community Sample.” Journal of Health and Social Behavior 21, no. 3 (September 1980): 219. doi:10.2307/2136617.

[13] Lazarus, Richard. S. "The stress and coping paradigm. Fifty years of the research and theory of RS Lazarus." An analysis of historical and perennial Issues 2 no. 5 (1998) 182-220.

[14] Lazarus, Richard S., and Susan Folkman. "Stress, appraisal, and coping.” Springer publishing company (1984).

[15] Folkman, Susan, Richard S. Lazarus, Christine Dunkel-Schetter, Anita DeLongis, and Rand J. Gruen. "Dynamics of a Stressful Encounter: Cognitive Appraisal, Coping, and Encounter Outcomes.” Journal of Personality and Social Psychology 50, no. 5 (1986): 992-1003. doi:10.1037/0022-3514.50.5.992. 
[16] Lazarus, Richard S., and Susan Folkman. “Transactional Theory and Research on Emotions and Coping." European Journal of Personality 1, no. 3 (September 1987): 141-169. doi:10.1002/per.2410010304.

[17] Carver, Charles S., Michael F. Scheier, and Jagdish K. Weintraub. “Assessing Coping Strategies: A Theoretically Based Approach.” Journal of Personality and Social Psychology 56, no. 2 (1989): 267-283. doi:10.1037/0022-3514.56.2.267.

[18] Nurmi, Jari - Erik, Sari Toivonen, Katariina Salmela - Aro, and Sanna Eronen. "Optimistic, approach - oriented, and avoidance strategies in social situations: three studies on loneliness and peer relationships." European Journal of Personality 10, no. 3 (1996): 201-219. doi:10.1002/(SICI)1099-0984(199609)10:3<201::AID-PER257>3.0.CO;2-\%23.

[19] Folkman, Susan, and Judith Tedlie Moskowitz. "Coping: Pitfalls and Promise.” Annual Review of Psychology 55, no. 1 (February 2004): 745-774. doi:10.1146/annurev.psych.55.090902.141456.

[20] Gabrhelová, Gabriela and Ferdinand Korn „Social and Emotional Intelligence of Managers in the Context of Law. "Management 2016: International Business and Management, Domestic Particularities and Emerging Markets in the Light of Research. Prešov University in Prešov (2016) p. 584-590.

[21] Oberuč, Jaroslav, Lajčin, Daniel and Dáša Porubčanová " Stress management in the Workplace.” Journal on Law, Economy \& Management. London: Eastern european developement agency 53 no. 2 (2014), 47-51.

[22] Stewart, Wayne H., and Philip L. Roth. "A Meta-Analysis of Achievement Motivation Differences Between Entrepreneurs and Managers." Journal of Small Business Management 45, no. 4 (October 2007): 401-421. doi:10.1111/j.1540627x.2007.00220.x.

[23] Aitken, Alicia, and Lynn Crawford. "Coping with Stress: Dispositional Coping Strategies of Project Managers." International Journal of Project Management 25, no. 7 (October 2007): 666-673. doi:10.1016/j.ijproman.2007.02.003.

[24] Albrecht, Karl. "Stress and the Manager.” Simon and Schuster (2010).

[25] Lusch, Robert F., and Bernard J. Jaworski. "Management controls, role stress, and retail store manager performance." Journal of Retailing 67 no. 4 (1991): 397.

[26] Callan, V. J., and C. Dickson. "Managerial Coping Strategies during Organizational Change.” Asia Pacific Journal of Human Resources 30, no. 4 (June 1, 1993): 47-59. doi:10.1177/103841119303000404.

[27] "Sunny” Hu, Hsin-Hui, and Chien-Wei Cheng. "Job Stress, Coping Strategies, and Burnout Among Hotel Industry Supervisors in Taiwan." The International Journal of Human Resource Management 21, no. 8 (June 2010): 1337-1350. doi:10.1080/09585192.2010.483867.

[28] Baumgartner, František, and Miroslav Frankovský. "Stratégie zvládania náročných situácií v kontexte osobnostných charakteristík." Praha: Testcentrum (2000).

[29] Brougham, Ruby R., Christy M. Zail, Celeste M. Mendoza, and Janine R. Miller. "Stress, Sex Differences, and Coping Strategies Among College Students." Current Psychology 28, no. 2 (February 11, 2009): 85-97. doi:10.1007/s12144-0099047-0.

[30] Křivohlavý, Jaroslav “Jak zvládat stres.” Grada Avicenum (1994).

[31] Armstrong, Michael. "Management a leadership." Grada Publishing as (2008).

[32] Mellahi, Kamel, and Adrian Wilkinson. "Managing and Coping with Organizational Failure: Introduction to the Special Issue." Group \& Organization Management 35, no. 5 (October 2010): 531-541. doi:10.1177/1059601110383404.

[33] Zhang, Lianying, Yingying Yao, and Tak Wing Yiu. "Job Burnout of Construction Project Managers: Exploring the Consequences of Regulating Emotions in Workplace." Journal of Construction Engineering and Management 146, no. 10 (October 2020): 04020117. doi:10.1061/(asce)co.1943-7862.0001913.

[34] Karlsen, Jan Terje, and Morten Emil Berg. "A Study of the Influence of Project Managers' Signature Strengths on Project Team Resilience." Team Performance Management: An International Journal 26, no. 3/4 (May 28, 2020): $247-262$. doi:10.1108/tpm-12-2018-0081.

[35] Burrows, James. "Improving Team Collaboration as a Project Manager." The Kabod 6.2 (2020): 4.

[36] World Health Organization. Mental health and psychosocial considerations during the COVID-19 outbreak, 18 March 2020. No. WHO/2019-nCoV/MentalHealth/2020.1. World Health Organization, 2020.

[37] Unterhitzenberger, Christine, Hannah Wilson, David James Bryde, Martin Rost, and Roger Joby. "The Stakeholder Challenge: Dealing with Challenging Situations Involving Stakeholders." Production Planning \& Control (June 10, 2020): 1-16. doi:10.1080/09537287.2020.1776907. 